
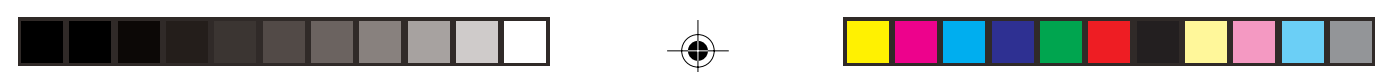

\title{
Theme Eco-journalism and security
}

\section{Anti-terror laws and the media after 9/11: Three models in Australia, NZ and the Pacific}

\begin{abstract}
This article reviews some of the main anti-terrorism laws in Australia and New Zealand and assesses their impact upon the media in the five years since the terrorist attacks on the United States in 2001. It also makes some observations about anti-terrorism laws in the Pacific Islands and recommends further research on this important topic. It identifies the main intrusions into press freedom emanating from such laws and finds quite different approaches with resultant impacts on media freedoms. Australia, while claiming to be a liberal democracy, has taken tough measures against terrorism at the expense of some press freedoms. New Zealand, with freedom of expression protected in its Bill of Rights, has implemented counter-terrorism measures without major limitations on media freedoms. Pacific Island nations, many troubled by internal strife, appear to have been slow to comply with even the very basic international protocols on counter-terrorism.
\end{abstract}

\section{MARK PEARSON and NAOMI BUSST \\ Bond University, Queensland}

$\mathrm{T}$

HIS ARTICLE chronicles the key anti-terrorism legislation enacted in Australia and New Zealand over the past five years and considers its impact on the media. It also raises some questions about developments in some Pacific island nations. More attention is given to the actual anti- 

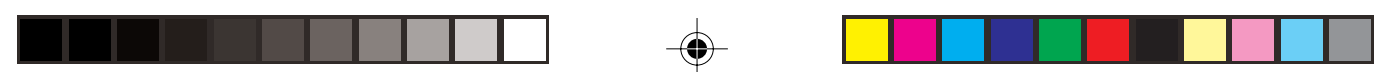

\section{ECO-JOURNALISM AND SECURITY}

terror laws in Australia and New Zealand because it is in these countries where there has been most legislative action in the area. The Pacific islands section is based mainly on Pacific Forum communiqués, individual nations' correspondence with United Nations authorities and specific legislation implemented in some countries. There are too many jurisdictions to allow comprehensive coverage of all Pacific Islands as well as difficulties accessing upto-date legislative compilations. That topic deserves closer scrutiny in a future project.

\section{Anti-terrorism and national security laws before $\mathbf{9 / 1 1}$}

Before examining anti-terrorism laws over the past five years it is important to note that media restrictions in the name of national security were in existence long before September 2001. As the Australian Law Reform Commission noted in its 2006 discussion paper on sedition laws (ALRC 2006), sedition and treason laws date back to feudal times as governments attempted to enforce allegiance to lords and monarchs (p. 51). Throughout the 19th and 20th centuries nations in the region maintained sedition and treason laws and used them occasionally against journalists. Pullan chronicles the use of sedition and seditious libel by governments against editors throughout colonial times (Pullan, 1994) and Pacific Media Watch reported sedition charges being brought against three individuals over a publication in Tonga in 2003 $(P M W, 2003)$ and New Zealand earlier this year.

In Australia, Hocking describes the post-2001 counter-terrorism initiatives as 'the second wave', given the substantial activity in developing national security measures from the late 1960s, largely in response to isolated terrorist incidents throughout the 1970s and political reviews of the operations of the Australian Security Intelligence Organisation (ASIO) (Hocking, 2004). The media operated under what Hocking called a system of 'voluntary restraint' (p. 82), such as the 'D-notice' agreements between major newspaper editors and the Australian Government preventing them reporting on sensitive security issues in the post-war era through until the late 1980s. Others were more specific, such as s. 92 of the Australian Security Intelligence Act 1979, which provides for a year's imprisonment for anyone who identifies an officer of the national security organisation other than its director-general.

Neither was New Zealand exempt from counter terrorism law prior to 9/11. As far back as the mid- to late 19th century, the government imple- 
mented 'martial law and other legal manoeuvres to quell Maori resistance' (Smith, 2003, p. 5). Smith (2003, pp. 5-15) traces the fascinating evolution of anti-terrorism measures in New Zealand from the Public Safety Conservation Act 1932, through the 1951 waterfront strike, the 1981 Springbok tour and its associated protests, the Rainbow Warrior bombing in 1985, amendments to the NZ Security Intelligence Service Act 1969 and Immigration Act in 1999, and implementation of various United Nations sanctions and conventions. Smith (2003, pp. 5-11) also also notes that the Public Safety Conservation Act of 1932, which was considered a violation of civil liberties, was abolished in 1987 after the terrorist bombing of the Rainbow Warrior with the introduction of the International Terrorism (Emergency Powers) Act 1987. The republication of David Robie's Eyes of Fire: The Last Voyage of the Rainbow Warrior (Robie, 2005) in a memorial edition brought home the historical significance of an international act of terrorism in New Zealand waters two decades on, particularly in the light of the post 9/11 security environment. Burrows and Cheer (2005, pp. 488-489) discuss the special emergency powers introduced in the wake of the Rainbow Warrior bombing in the form of the International Terrorism (Emergency Powers) Act 1987. As in Australia, the post-2001 actions could not be divorced from a history of antiterror legislation in that jurisdiction.

In the Pacific Islands throughout history, as in the Middle East today, one person's terrorist might be another person's 'freedom fighter', and legislative responses to rebellions could be viewed as early evidence of 'counter-terrorism measures'. Examples include the rebellion in Bougainville, Papua New Guinea, from 1988 until 1997; the Tongan government's legislative measures against the Human Rights and Democracy Movement and the media from the late 1990s; Fiji's responses to its coups in 1987 and 2000; and actions against militants in the Solomon Islands since the late 1990s. That said, most of these responses could not be classified as 'anti-terrorism laws', but more often the vigilant (or some might say 'repressive') use of existing laws against anti-government elements.

\section{Anti-terror laws in Australia and their impact}

The best resource on anti-terrorism legislation in Australia, with useful links to international information, is the Australian Parliamentary Library's Terrorism Law Directory (Library, 2006). At 6 June 2006, the site listed 31 coun- 

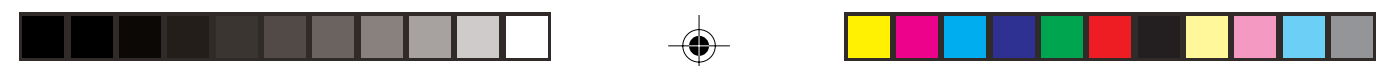

\section{ECO-JOURNALISM AND SECURITY}

ter-terrorism Acts passed by the Australian Parliament since September 2001, with four Bills introduced during 2006 still progressing through the legislative process. It registered 18 parliamentary committee reports into proposed legislation over that period. The directory listed 26 federal Acts and six Regulations related to terrorism already in force before 11 September 2001. Of course, not all of this counter terrorism legislation affects the work of journalists and media organisations.

However, many of the changes have the potential to affect journalists in their reporting of terrorism-related stories, in the following ways:

- Leaving reporters exposed to new detention and questioning regimes;

- Exposing journalists to new surveillance techniques;

- Seizure of journalists' notes and computer archives;

- Exposing journalists' confidential sources to identification;

- Closing certain court proceedings, thus leaving matters unreportable;

- Suppressing certain details related to terrorism matters and exposing journalists to fines and jail if they report them;

- Restricting journalists' movement in certain areas where news might be happening;

- Exposing journalists to new risks by merely associating or communicating with some sources; and

- Exposing journalists to criminal charges if they publish some statements deemed to be inciting or encouraging terrorism.

Media organisations and representative bodies including the Australian Press Council and the journalists' union, the Media Entertainment and Arts Alliance (MEAA), drafted submissions to parliamentary committees examining the legislative proposals and some of their concerns were addressed while most were not. Discussion of the major issues raised and some ensuing cases follows.

The MEAA detailed most of the major issues of concern to journalists in its press freedom reports in 2005 and 2006. In its 2005 report (MEAA, 2005) it listed the ASIO Legislation Amendment Act 2003 as the law of main concern to journalists because of its effective limits on any media exposure of any active operation by the national security force under warrant for up to two years, 'even if the operation is in violation of international human rights conventions'. The Act lists two offences for individuals who disclose 'opera- 

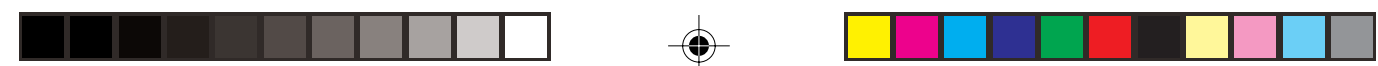

\section{ECO-JOURNALISM AND SECURITY}

tional information' relating to the enforcement of an ASIO warrant, punishable by five years' imprisonment. The first (s. 34VAA) prevents disclosure of any information relating to such a warrant for 28 days after its issue. While it is designed to stop those questioned talking to other terrorists, as the MEAA points out (p. 5), it also '...stops those who have been questioned by ASIO and/or their lawyers from talking to the media'. No matter how arbitrary their arrest, or what maltreatment they may have suffered, suspects can go to jail for up to five years if they talk about their experience. There are no public interest or media exemptions to the requirement, although disclosures of operational information by anyone other than the subject of a warrant or their lawyer requires the discloser to have shown 'recklessness' in doing so (s. 34VAA(3) ). 'Recklessness' requires both an awareness of the results of an action and a disregard for the consequences, but the extent to which journalists would be able to use public interest grounds as a motivation remain unclear (MEAA, 2005, p. 5).

The second offence under s. 34VAA (2) extends the ban on the disclosure of operational information for a further two years after the expiry of an ASIO warrant. As the MEAA points out $(2005$, p. 5), new warrants can be issued making the gag effectively indefinite. This also carries a five year jail sentence. The Act's definition of 'operational information' is broad, covering (at 34VAA (5)):

- information that was or is in ASIO's possession;

- a source of information that ASIO has other than the subject of the warrant; or

- an operational capability, method or plan of ASIO.

The reach of these provisions extends overseas as well, so individuals or media in other countries making such disclosures about ASIO operations face potential prosecution in Australia (s. 34VAA (4) ).

While no media outlets have yet faced prosecution under this legislation (or perhaps they have, we just don't know!), the Bills Digest memorandum to federal parliamentarians quoted this item from the Weekend Australian on 8 November 2003, as potentially in breach (Library 2003):

At least one of the seven men raided by armed police and ASIO on suspicion of being linked to al-Qaeda suspect Willie Brigitte was detained and questioned this week under new national anti-terrorism laws. The questioning of the suspect marks the first time ASIO has used its

PACIFIC JOURNALISM REVIEW 12 (2) 200613 

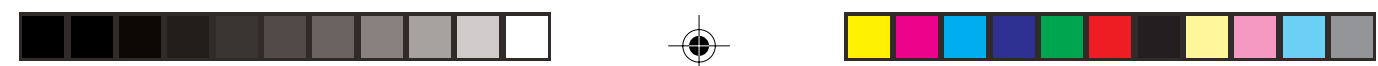

\section{ECO-JOURNALISM AND SECURITY}

contentious anti-terror powers, which were introduced in July this year in the wake of the Bali bombing.

The man was taken to the Australian Crime Commission offices in Sydney's CBD for questioning in two eight-hour sessions about his connections to Brigitte, who was deported to France last month.

The man was later released and no charges have been laid.

(Chulov, 2003)

In their submission to the Security Legislation Review Committee in 2006, the Victorian Council for Civil Liberties suggested the new disclosure offences almost certainly prohibited reporting of this type.

Even repeating the content of the story in this article in order to illustrate the type of information that cannot be reported is probably illegal. So much was acknowledged by the Attorney-General, Philip Ruddock (Walters, 2006).

If that is indeed the case, then the Australian Parliament itself continues to be in breach of the legislation for as long as it leaves the article sitting on its own website in the Bills Digest cited above (Library, 2003). Other items of antiterrorism legislation of concern to media advocates were:

- Criminal Code Amendment (Terrorist Organisations) Bill 2003 and the Anti-Terrorism Bill (no. 2) 2004; prohibiting 'association' with terrorist organisations. This has the potential to impede journalists trying to report on such groups.

- Amendments to the Telecommunications (Interception) Act 1979, enacted in 2004 and 2006; allowing enforcement agencies to obtain warrants to access stored communications such as sms, mms, email and voicemail messages held by journalists. This might jeopardise the identity of their confidential sources.

In its 2006 report, the MEAA suggested journalists now needed to assume that their conversations with sources on terrorism stories would be intercepted as one of the 2006 amendments allows phone tapping of third parties to suspected terrorist plots.

Those journalists who do contact terror suspects for a story may have their phone tapped, giving authorities access not only to conversations 

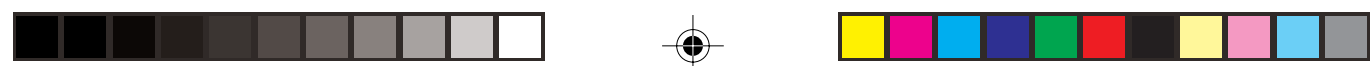

ECO-JOURNALISM AND SECURITY

with the suspect but those of other innocent sources. At any time police could be listening, obliterating any professional right the journalist has to protect the confidentiality of their source (MEAA 2006).

The National Security Information (Criminal Proceedings) Act 2004 allows prosecutors and courts to use national security information in criminal proceedings while preventing broader disclosure of such information including, in some circumstances, disclosure to the defendant. The legislation as passed gives courts the discretion to decide whether to hold proceedings in camera and requires the publication of reasons for such a decision. In the Lodhi case (Lodhi v. R. [2006] NSWCCA 101), the NSW Court of Appeal held the trial judge had gone to some lengths to keep the court open, indicating that the judiciary was using its discretion to maintain open justice as far as practicable. Lodhi was sentenced to 20 years' imprisonment on 23 August 2006, for planning a terrorist attack on Australia (King, 2006).

The Anti-Terrorism Act (No. 2) 2005 was the piece of legislation prompting the harshest criticism from press freedom and civil rights bodies. Most controversially, the updated legislation on sedition offences that had been dormant for more than half a century, prompted stringent protests from media groups. They were modernised by being replaced with a suite of five offences prohibiting individuals from 'urging' others to use 'force or violence' in certain contexts, with a specific 'good faith' defence (ALRC, 2006). In response to the public objections to the sedition provisions, and a recommendation from a Senate committee that they be dropped, the Attorney-General Philip Ruddock took the unusual step of agreeing that the sedition laws would be subject to a review after the legislation had been passed. The Australian Law Reform Commission embarked on that process and in July 2006 handed down its report on the new sedition laws (ALRC2, 2006), recommending that the government:

- drop the 'red rag' term 'sedition' from federal laws;

- further refine the existing law to require the Crown to prove that a person urged others to use force or violence against community groups or the institutions of democratic government, and with the intention that this violence would eventuate; and

- lead a process through the Standing Committee of Attorneys-General to reform state and territory laws in this area 'which mostly are a good deal worse than the federal law'.

PACIFIC JOURNALISM REVIEW 12 (2) 200615 

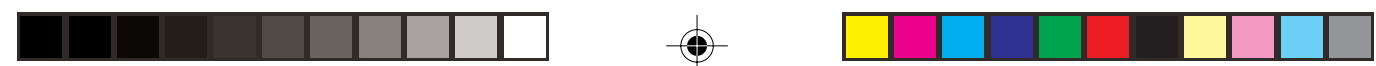

\section{ECO-JOURNALISM AND SECURITY}

ALRC president Professor David Weisbrot said in a statement that the main concern of the reforms was to preserve free expression while combating terrorism.

Once you get beyond the term, there is support for the basic thrust of the new offences. The Report recognises that free speech and robust political debate are cornerstones of Australian society (Weisbrot, 2006).

As this article went to press, the Australian government was yet to implement any of the recommendations, although the Attorney-General Philip Ruddock issued a statement on its tabling in Parliament in September 2006 acknowledging its findings (Ruddock, 2006). From mid-2006 the first evidence began to surface of the impact of these laws upon the media and other researchers.

- Federal Police served search warrants on a journalist from the Age newspaper in Melbourne, Ian Munro, and upon the ABC's Four Corners programmes, demanding their notes and tapes of interviews with alleged terrorist 'sleeper' Jack Thomas (Burrow, 2006). In August, Thomas had won an appeal against a conviction under s. 102.6 of the Criminal Code 1995 prohibiting receiving funds from a terrorist organisation which had been inserted under anti-terror amendments in 2002 and 2003. The appeal court had quashed the conviction on the basis of the inadmissibility of the police record of an interview with the accused. In the aftermath, the Director of Public Prosecutions requested a retrial and the journalists' materials were presumably to be used as evidence of certain admissions by the accused because they covered similar ground to the inadmissible police evidence. The Age journalist cooperated with the police, defusing a situation where they would have been tempted to use seizure powers. On 27 August 2006, a federal magistrate issued the nation's first 'control order' on Thomas under section 104.4 of the Criminal Code, restricting his movements, requiring him to report to police, and banning his contact with a long list of terrorism organisations (Library, 2006).

- An academic who had been awarded an A $\$ 829,000$ Australian Research Council grant was forced to change his research design after being warned by Attorney-General Ruddock that his proposed interviews with international terrorist leaders would leave him in contravention of the anti-terror laws banning association with terrorists (Edwards, 2006). The development reinforced concerns that Australian journalists could face prosecution for interviewing 

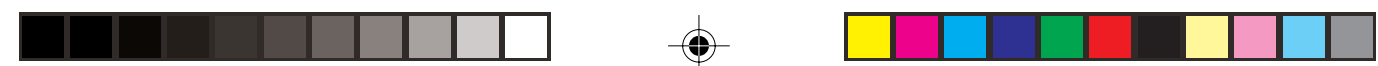

ECO-JOURNALISM AND SECURITY

terrorist leaders while on assignment overseas. These two recent developments against reporters and researchers highlight the fact that Australian journalists are working in a new environment of scrutiny and restriction-both express and implied-five years after 9/11.

\section{Anti-terror laws in New Zealand and their impact}

While New Zealand has also strengthened its counter-terrorism laws since 2001, its changes have not been as far-reaching as Australia's, nor have they generated the level of media and public outcry.

The key source on New Zealand's anti-terror developments is John E. Smith's report, researched as part of his assignment with the Ministry of Justice under the Ian Axford Fellowship in Public Policy. His project was titled The balancing act of governmental efforts against terrorism financing: curtailing the funding for terrorists while protecting civil liberties (Smith, 2003). In it he explored the effects and effectiveness of New Zealand's recent antiterrorism measures, particularly the Terrorism Suppression Act enacted in October 2002 and predecessor regulations adopted after the 11 September 2001 terrorist attacks in the US. His focus was on assessing their impact upon terrorists trying to channel funds through New Zealand and the effects of such laws on civil liberties.

Unlike Australia's 30-plus legislative changes, New Zealand featured two main anti-terrorism Acts: the Terrorism Suppression Act and the CounterTerrorism Act. While each had implications for journalism and civil liberties, each had the New Zealand Bill of Rights Act 1990 as a backdrop which, at Section 14, states:

Everyone has the right to freedom of expression, including the freedom to seek, receive, and impart information and opinions of any kind in any form.

Interestingly, the committee considering the original Terrorism Suppression Bill was due to report back to Parliament on 13 September 2001 after five months of consideration (Smith, 2003, p. 15). In the light of the events of 9/ 11, and the subsequent strongly worded Resolution 1373 of the United Nations Security Council, the Bill was revisited and redrafted by 8 November 2001. It was eventually passed on 8 October 2002, with several amendments.

The Bill was designed to insert into New Zealand law the obligations

PACIFIC JOURNALISM REVIEW 12 (2) 200617 

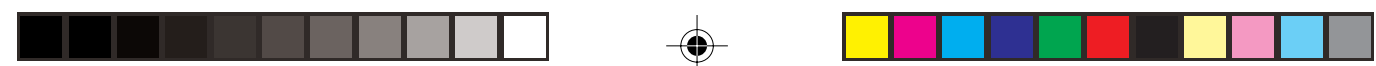

\section{ECO-JOURNALISM AND SECURITY}

pertaining to international bombing and financing conventions and the UN Security Council Resolution 1373 in response to the events of 11 September 2001. It defined terrorism and set out the definitions and penalties for terrorist bombing, the financing of terrorism, recruitment into and participation in terrorist groups, provisions for designation of terrorist organisations, duties to report suspicions about property held by suspected terrorists and customs' powers over such property and procedures for forfeiture of property.

The House of Representatives review of the legislation conducted during 2005 (Yates, 2005) raised the following issues with respect to the Act:

- the process for making terrorist designations pursuant to UN Security Council resolutions

- the extension of terrorist designations by the High Court

- the 'avoidance of doubt' provisions.

However, the House recommended only that it take note of judicial comments if further legislation was considered. There was no major protest against the legislation from media groups, most likely because it involved no direct threat to the work of journalists and was largely bringing New Zealand into line with international anti-terrorism practices.

The second major legislative initiative was the Counter Terrorism Act 2003 which amended the Terrorism Suppression Act 2002, the Crimes Act 1961, and a number of other Acts, to:

- implement in domestic law the requirements of the Convention on the Marking of Plastic Explosives for the Purpose of Identification and the Convention on the Physical Protection of Nuclear Materials;

- implement in domestic law the remaining obligations from United Nations Security Council Resolution 1373; and

- enhance the ability of government agencies to respond to terrorist threats through investigative powers and legislative provisions identified as necessary from an inter-agency review of domestic legislation. These powers and provisions cover different types of offences that could be committed or threatened by a terrorist or other individual (Foreign Affairs, 2003).

Much of the legislation involved New Zealand's compliance with international obligations and extended police and customs powers to deal with threats such as the introduction of animal diseases.

However, some elements were of concern to journalists, most notably the third of the three points above, involving:

18 PACIFIC JOURNALISM REVIEW 12 (2) 2006 

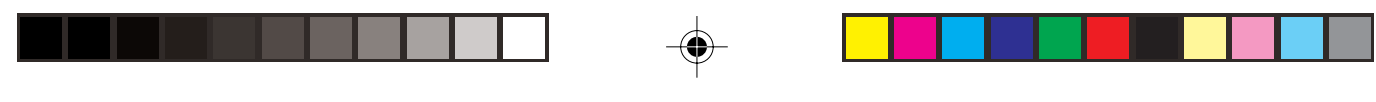

\section{ECO-JOURNALISM AND SECURITY}

- New crimes for the harbouring or concealing of terrorists;

- Powers for enforcement officers to use tracking devices with and without warrants; and

- Computer access powers for law enforcement officers.

The amendment to the Terrorism Suppression Act with the greatest potential implications for journalists was section 13A related to the harbouring or concealing of terrorists. That section states:

A person commits an offence who, with the intention of assisting another person to avoid arrest, escape lawful custody, or avoid conviction, harbours or conceals that person

(a) knowing, or being reckless as to whether, that person intends to carry out a terrorist act; or

(b) knowing, or being reckless as to whether, that person has carried out a terrorist act.

Conviction carries a penalty of up to seven years in jail. This section has the potential to expose journalists to conflicts over the identification of their sources, particularly for reporters who might be investigating the activities of potential terrorist groups. Sections 14 to 19 give New Zealand authorities extraterritorial jurisdiction over such acts, meaning New Zealanders working as foreign correspondents who interview terrorists in other countries such as Iraq may fall foul of such laws. However, at the end of 2005 no prosecutions had been brought under the Act (Yates, 2005) and media outlets had not protested against the press freedom implications of these sections, perhaps because of the balancing free expression guarantees of the Bill of Rights Act. In fact, the Yates report noted in a footnote (Yates, 2005) that the NZ government had not yet used its anti-terrorism legislation to designate any terrorist individual or group not included on the UN list, while Australia had listed 88 individuals or groups in addition to the UN list.

Australia had reinvigorated its sedition laws in late 2005 but was moving towards abolishing the term in late 2006. However, New Zealand had actually brought its first sedition charge in three decades against a political magazine editor in June 2006 (Diaz, 2006). Freelance writer, political protester and blogger Timothy Selwyn was sentenced to two months' jail for smashing the electoral office window of Prime Minister Helen Clark with an axe and leaving a note calling for others to do likewise. Newspaper editorials be- 

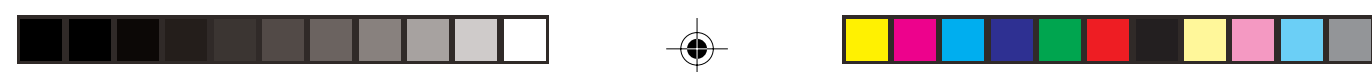

\section{ECO-JOURNALISM AND SECURITY}

moaned the implications for free expression.

The other two major changes with the potential to impact upon journalists were to do with tracking devices and computer access. Both were amendments to the Summary Proceedings Act 1957, giving police new general powers in this area. The tracking device powers were previously only available for investigations into drug-dealing offences. Now sections 200A-P of the Summary Proceedings Act confers certain powers on enforcement agencies to use such devices, both with and without warrants, "while ensuring that New Zealand Bill of Rights Act rights are preserved' (Foreign Affairs, 2003). In an extreme situation an investigative journalist researching a story on terrorism might well find such a tracking device being used on him or her, thus compromising any obligation of confidentiality to his or her sources.

A similar concern over source confidentiality comes with the insertion of s.198B into the Summary Proceedings Act 1957, giving police powers with a search warrant to access computer data and obliging the computer owner to provide access passwords so police can retrieve information from it. A fine of \$2000 or imprisonment for three months awaits a journalist who refuses to co-operate under fear that his or her confidential sources may be compromised in the process. The greater concern here is not just the protection of potential terrorists, but the protection of all other confidential sources for other stories who may be identifiable via email records, contact databases or other documents on the reporter's hard disk.

While some scholars and commentators have found shortcomings with the terrorism laws' infringements upon civil liberties (Conte, 2005) and privacy (Slane, 2003), there has not been the scale of media outcry over the legislation compared with Australia. To the contrary, in some eyes the media were seen to be manipulating the terrorism story to their own ends. Price (2004, pp. 124-130) showed how sloppy reportage led the New Zealand media to, firstly, wrongly target Algerian national Ahmed Zaoui as a terrorist, allowing them to cover his arrest and detention, and later champion the call for his exoneration. Even later the media quoted from European intelligence agencies to make new allegations about his guilt. The government had relied on classified security information to declare Zaoui a threat to national security and issued a Security Risk Certificate against him, Price recounted (p. 124). He itemised the reporting errors that had led to the story in the New Zealand Herald about the case, claiming the reports may have endangered 

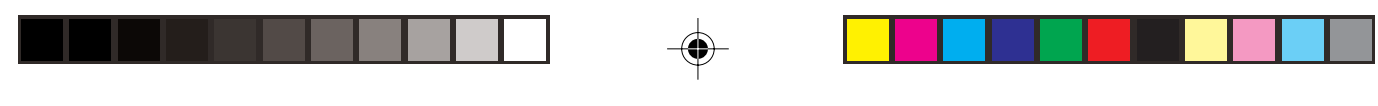

ECO-JOURNALISM AND SECURITY

Zaoui's life and used unreliable sources. Meanwhile, there was concern over the jailing of Selwyn for sedition. While it was an unusual case involving a dissident at the fringe of journalism, the incident seemed to send a message to media organisations that although New Zealand may not have as many new anti-terrorism laws, the government was still willing to use ancient charges like sedition against extreme outbursts of free speech.

\section{Anti-terror laws in Pacific nations and their impact}

As outlined at the outset, the counter-terrorism measures in the Pacific islands and their impact on the media are deserving of their own study. This will present substantial challenges for the researcher dealing with patchy information across several jurisdictions. While tiny Pacific island nations might seem a world away from the activities of terrorist organisations like alQaeda, there is concern that such countries could be used for money laundering or firearms acquisition by such organizations or more directly used as the base for terrorist attacks on other targets if security is not up to international standards. Further, international definitions of terrorist acts could be applied to civil disturbances and military coups in East Timor, the Solomon Islands and Fiji in recent years. Thus, their compliance with international treaties in this regard is of importance to the international community. That they do so with due regard for civil liberties and media freedom is of equal concern.

For the purposes of this article, some basic information on countries that have accessable legislation and some data on international compliance will be reviewed. The Pacific Island Legal Information Institute (www.paclii.org) lists anti-terrorism legislation enacted in Samoa, Tonga, Vanuatu and the Marshall Islands since 2002. Several editors, news executives, lawyers and academics in Pacific island nations have corresponded with the author to provide some basic information on anti-terrorism laws and their impacts, if any, upon the media. The reviewers of this article have also kindly provided some information.

The United Nations established the Counter-Terrorism Committee (known by its acronym: the CTC) under Resolution 1373. It is made up of all 15 members of the Security Council. The CTC monitors the implementation of resolution 1373 by all states and tries to increase the capability of states to fight terrorism. Its correspondence on progress with anti-terrorism initiatives at all nations is recorded at its website www.un.org/Docs/sc/committees/1373/ reports.html . 

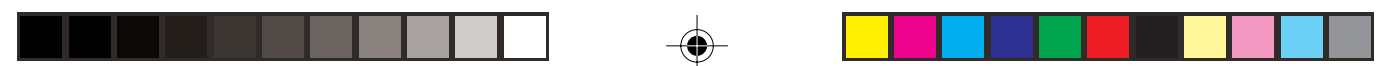

\section{ECO-JOURNALISM AND SECURITY}

Correspondence with Pacific Island nations can be accessed there, and some country reports are indicative of the considerable work yet to be done in bringing Pacific nations into compliance with the basic elements of Resolution 1373. 'Combating terrorism itself has not, unsurprisingly, been seen as a top priority,' Pacific Forum Secretariat Secretary-General Greg Urwin, reported (Urwin, 2004). The challenges of everyday domestic obstacles of delivering the basic services to citizens are more important, particularly in view of civil disturbance in some countries.

Papua New Guinea's letter, dated 5 September 2003, for example, features 11 pages of explanation of the substantial steps left for that country to reach compliance with the 2001 resolution.

Tonga's correspondence at http://daccessdds.un.org/doc/UNDOC/GEN/ N03/413/83/PDF/N0341383.pdf?OpenElement features that kingdom's responses at 20 June 2003 to 25 perceived shortcomings or lack of information identified by the CTC. Several of the Resolution 1373 requirements had been addressed in legislative form but the CTC was querying the country's ability to implement them. It listed $10 \mathrm{UN}$ terrorism conventions Tonga had ratified since 2001.

Another story of Pacific nations' difficulties in implementing anti-terrorism measures can be found in the communiqués from the Pacific Islands Forum meetings from 2002 through until 2005 (Secretariat, 2006). At the 33rd Pacific Islands Forum in Suva, leaders of 16 nations signed off on the Nasonini Declaration on Regional Security which recognised 'the importance of global efforts to combat terrorism and to implement internationally agreed antiterrorism measures'. However, it stated 'further urgent action was required of some member states and recommitted to full implementation of relevant legislation'.

A year later at the 34th Forum in Auckland, frustration with the lack of progress in some nations was expressed when the communique 'urged Forum Island Countries to fully enact the relevant legislation under the Honiara Declaration by the end of 2003, in accordance with the Leaders' commitment under the 2002 Nasonini Declaration' (Thirty-Fourth Pacific Islands Forum Communiqué). When a further year had passed at the 35th Forum in Apia, Samoa, the concerns in the communiqué were expressed in more urgent terms:

Leaders noted with concern the major security vulnerabilities facing the Pacific region and urged members who ha[d] not yet done so to

22 PACIFIC JOURNALISM REVIEW 12 (2) 2006 

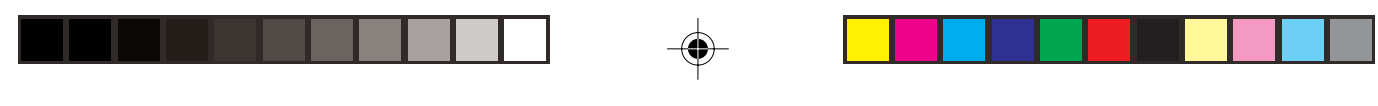

\section{ECO-JOURNALISM AND SECURITY}

enact and implement existing model legislative provisions including those addressing terrorism and transnational organised crime, illicit drugs, weapons control and transport security... Leaders also recognised the serious risks to the region's trade and tourism of non-compliance with international transport security measures.

This followed a stern warning at the Forum Regional Security Committee meeting in June 2004 by Forum Secretariat Secretary-General Greg Urwin, who said Forum island countries had not seen terrorism as a top priority given the other substantial social and economic problems they confronted. He said many might not see a terrorist attack as 'a high likelihood', but he disagreed:

Let there be no doubt - and recent developments here in Fiji do seem to leave little room for that - that our region is being targeted for criminal activities such as the transit of illicit drugs, people smuggling, money laundering, and identity fraud. We are being targeted because of our lack of strong uniform legislation and inadequacies in human, financial and technical resources. The challenges to governance in our region e.g. corruption, increasing poverty and lawlessness, also make parts of it attractive to transnational organised crime. And the vulnerability of our region to transnational organised crime means that it is also vulnerable to terrorist activities, because it seems well demonstrated that the networks that establish and maintain transnational criminal activities can also maintain and fund terrorist activities. (Urwin 2004)

By the 36th Forum meeting in Papua New Guinea in October 2005, the Forum Communique indicated some progress with a Pacific Regional Policing Initiative and a Pacific Transnational Crime Coordination Centre, but leaders 'acknowledged that the region remains vulnerable to the activities of transnational organised criminal groups and terrorist organisations' and 'noted the importance of enacting legislation to implement obligations countering terrorism, and welcomed New Zealand's offer of assistance to Forum Island Countries in implementing their UNSCR 1267, 1373 and 1540 reporting obligations'.

In short, the difficulty in Pacific Island nations seems to be in meeting basic international anti-terrorism standards rather than being too vigorous in their development and implementation. Personal correspondence with media contacts throughout the major Pacific nations in June 2006 revealed no evi-

PACIFIC JOURNALISM REVIEW 12 (2) 200623 

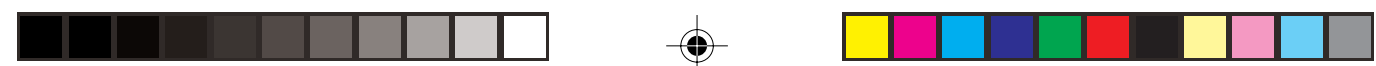

\section{ECO-JOURNALISM AND SECURITY}

dence of impact of the scant counter-terrorism laws on journalism. That said, as Robie has chronicled, media outlets in Pacific countries have traditionally faced considerable governmental obstacles to their reportage and many governments do not need the excuse of new anti-terror laws to limit media rights (Robie 2004).

\section{Anti-terror and the media in the Pacific region: three models?}

It seems three models have emerged from our survey of the impact of counter-terrorism initiatives on the media in Australia, New Zealand and from this brief survey of the Pacific Islands.

Australia has clearly taken a strong anti-terrorism position, reflecting its partnership with the United States and the United Kingdom in the so-called 'Coalition of the Willing' invasion of Iraq in 2003 and its loss of 92 lives in the terrorist bombings in the tourist hub of Bali, Indonesia, in 2002 and 2005. Its spate of legislation since 2001 has made it a model jurisdiction for the tightening of the powers of enforcement and security agencies in the battle against terrorism, but in the process it has drawn strong criticism from civil rights groups and media organisations for compromising the basic freedoms of its citizens and its press. Journalists have faced real and potential impositions, including restrictions on their reportage of some terrorism operations, new surveillance and interception powers jeopardising the confidentiality of journalists' sources, and a reinvigoration of ancient sedition laws. Two recent examples offer evidence the new laws are starting to bite, with reporters and researchers affected.

The New Zealand approach appears, in a mere count of legislative initiatives, to be more moderate. Despite some criticism from academics and civil libertarians, New Zealand seems to have met international obligations in its anti-terrorism initiatives without presenting many new challenges to civil liberties and media freedoms. However, a mere count of new legislative instruments is not enough. Much comes down to interpretation and enforcement. New Zealand's two main rafts of legislation since 2001 have increased the potential of law enforcement agencies to compromise journalists' sources via tracking devices and computer access. Futhermore investigative journalists chasing a terrorism story may find themselves vulnerable to new laws on the 'concealing' of terrorists, particularly if their foreign reportage brings them into contact with terrorism operatives as sources. And its 2006 jailing of a 
pamphleteer under the ancient law of sedition indicates the New Zealand legislators may feel pre-9/11 laws suit their post 9/11 needs.

Our short Pacific study has shown many of those countries, faced with major domestic social and economic challenges, have failed to implement the bare minimum anti-terrorism initiatives expected by the United Nations conventions to which they are signatories. While many have a history of random clampdowns on the media under existing laws, most have not placed new impediments on journalists by using anti-terrorism initiatives as an excuse. This leaves the Pacific island media relatively free to report upon the considerable shortcomings in their own countries' anti-terrorism strategies and to report openly upon any terrorism activity if and when it arises. These are stories which need to be researched and told for the sakes of Pacific island citizens and the broader Pacific and world communities because it is feasible that such jurisdictions could be used for attacks on tourists, as training grounds for terrorist operatives, and as convenient sites for gun running and money laundering by terrorist organisations.

The topic deserves further research on a range of fronts, particularly concerning the role of New Zealand's Bill of Rights Act in the post-9/11 legislative process. All legislation there must be referred to the Ministry of Justice for a review of its compliance to the Act before it is tabled in Parliament. Australia has no such Bill of Rights, so the role of this process is of interest and importance. Australian journalists seem to be paying the price for a lack of a Bill of Rights to protect freedom of expression and other basic human rights (despite High Court decisions in the 1990s developing an implied freedom to communicate on matters of government and politics) (Chesterman, 2000).

Only hindsight will tell us which of the three approaches is the superior one. If Australia's more vigilant strategy serves to prevent a terrorist attack, perhaps the sacrifice of press freedoms will prove to have been worthwhile. If New Zealand's apparently softer line results in another Rainbow Warriortype incident then media defenders of their press freedom will be quick to turn into critics of the nation's lax security measures, just as they changed their tune in the Zaoui affair (Price, 2004). Nevertheless, the erosion of media freedom in democratic nations must be heartwarming to the very terrorists the new laws are designed to target. If their aim is to use terrorism to erode the basic platforms of democratic societies, then these post-9/11 laws 

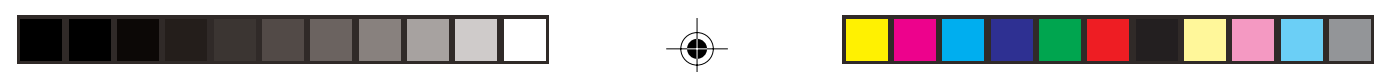

\section{ECO-JOURNALISM AND SECURITY}

might be serving their objective by damaging the centuries-old principle of freedom of the press. Justice Aharon Barak, President of the Israeli Supreme Court, encapsulated the dilemma in 2002 when he said: 'Terrorism does not justify the neglect of accepted legal norms. This is how we distinguish ourselves from the terrorists themselves.' (Barak, 2002)

\section{References}

ALRC2 (2006). Fighting words report. a review of sedition laws in Australia. Report 104.

ALRC (2006). Review of sedition laws. Discussion paper. Canberra: Australian Government, Australian Law Reform Commission.

Barak, A. (2002). A judge on judging: the role of a supreme court in a democracy. Harvard Law Review, 116(16): pp. 151-152.

Burrow, V. (2006, September 4). Thomas: warrant served on Age man. The Age, Melbourne, p. 5.

Burrows, J., and Cheer, U. (2005). Media law in New Zealand. Fifth edition. South Melbourne: Oxford University Press.

Chesterman, M. (2000). Freedom of speech in Australian law: a delicate plant. Ashgate Dartmouth: Aldershot.

Chulov, M., and Harris, T. (2003, November 8). ASIO flexes fresh muscle. Weekend Australian, Sydney, p. 1.

Conte, A. (2005). Crime and terror: New Zealand's criminal law reform since 9/11. [Electronic Vresion] New Zealand Universities Law Review, 21(4). (Retrieved 22 September 2006): www.nzulr.com/archives/vol21no4.htm

Diaz, D. (2006, July 19). Fraud added to sedition. Dominion Post, Wellington, p. 3.

Edwards, V., and Cameron S. (2006, September 13). Professor warned off talking to terrorists. The Australian:, pp. 1 and 4.

Foreign Affairs, Defence and Trade Committee. (2003). Counter-terrorism bill commentary. Wellington, New Zealand: Foreign Affairs, Defence and Trade Committee, Parliament of NZ.

Hocking, J. (2004). Terror laws: ASIO, counter-terrorism and the threat to democracy. Sydney: UNSW Press.

King, D. (2006). Terror plotter gets 20 years. The Australian, Sydney, p.1.

Library, P. (2003). Bills Digest No. 68 2003-04, ASIO Legislation Amendment Bill 2003. Canberra: Parliament of Australia.

Library, P. (2006). Terrorism law. Parliament of Australia. 2006: Directory of antiterrorism legislation and links.

MEAA (2005). Turning up the heat: the decline of press freedom in Australia 20012005. Inaugural Media, Entertainment and Arts Alliance report into the state of press freedom in Australia from September 11, 2001- 2005. Sydney: MEAA.

MEAA (2006). The media muzzled: Australia's 2006 press freedom report. The Media, Entertainment and Arts Alliance 2006 report into the state of press freedom in Australia. Sydney: MEAA.

26 PACIFIC JOURNALISM REVIEW 12 (2) 2006 

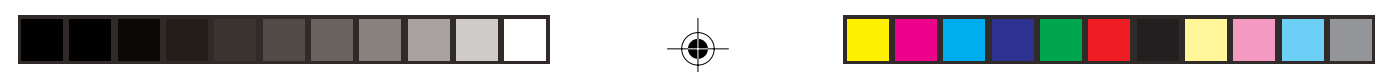

ECO-JOURNALISM AND SECURITY

$P M W$ (2003, May 21 ). TONGA: Court acquits three on sedition charges. 2006. Press freedom newsletter.

Price, S. (2004). Terrorism by media: coverage of the Ahmed Zaoui affair. Pacific Journalism Review 10(1): pp. 124-130.

Pullan, R. (1994). Guilty secrets: free speech and defamation in Australia. Glebe, NSW: Pascal Press.

Robie, D. (2004). Mekim nius: South Pacific media, politics and education. Suva: University of the South Pacific Book Centre.

Robie, D. (2005). Eyes of fire: the last voyage of the Rainbow Warrior. Memorial edition. Auckland: Asia Pacific Network.

Ruddock, P. (2006). ALRC report on sedition laws tabled. Media Release 177/2006, Attorney-General. 2006.

Secretariat, P. I. F. (2006). Forum Communique. 2006.

Slane, B. H. (2003). Counter-terrorism bill. Report by the Privacy Commissioner to the Minister of Justice in relation to the Counter-Terrorism Bill. Auckland: Office of the Privacy Commissioner, New Zealand: 11.

Smith, J. E. (2003). New Zealand's anti-terrorism campaign: balancing civil liberties, national security and international responsibilities. Ian Axford Fellowship report. Wellington, NZ: US Department of Justice.

Urwin, G. (2004). Opening address to the Forum Regional Security Committee Meeting. Pacific Forum Regional Security Committee Meeting, Nadi, Fiji, Pacific Forum Secretariat.

Walters, B. a. T., J-C. (2006). Victorian Council for Civil Liberties Submission to the Security Legislation Review Committee. S. L. R. Committee. Canberra: AttorneyGeneral's Department.

Weisbrot, D. (2006). Support for anti-violence measures, not 'sedition'. ALRC. Media releases. A. L. R. Commission. Sydney: Australian Law Reform Commission. 2006.

Yates, D. (2005). Review of the terrorism suppression act 2002. Report of the Foreign Affairs, Defence and Trade Committee. Wellington: New Zealand House of Representatives: 15 .

Dr Mark Pearson is professor of journalism at Bond University, Gold Coast, Australia.

Naomi Busst is a doctoral candidate and research assistant at Bond University. The authors acknowledge research funding from Bond University and thank Pacific Journalism Review reviewers for their suggestions. An earlier version of this paper was delivered to the Fifth Media Law Advocates Training Programme, Oxford University, in July, 2006.

mpearson@staff.bond.edu.au

nbusst@student.bond.edu.au

PACIFIC JOURNALISM REVIEW 12 (2) 200627 